\title{
Participatory Land Use Planning to Enhance Rural Livelihoods in Eastern Maharashtra Plateau of Central India
}

\author{
V. Ramamurthy* \\ ICAR-National Bureau of Soil Survey and Land Use Planning, Regional Centre, \\ Hebbal, Bangalore-560024, Karnataka, India \\ *Corresponding author
}

\section{A B S T R A C T}

Integration of farmers preference, bio-physical, socio-economic resources with scientific evaluation is important for viable land use planning to conserve and use available resources in a sustainable manner. In many countries, participatory approach has proven to

\section{Keywords}

Participatory land use planning, India, Soil suitability, Land use changes

Article Info

Accepted:

07 March 2018

Available Online:

10 April 2018 be essential in successful planning and implementation of land use plans. The main aim of this study to enhance the rural livelihoods through participatory land use planning approach. This paper reports Participatory Land Use Planning (PLUP) methodology developed by integration of farmer's preference through PRA, bio-physical evaluation of soils by land evaluation and socio-economic resources and tested in Eastern Maharashtra plateau of Central India. The study revealed that land use planning is dependent not only on the soil suitability criteria but also on the market forces, economic situation of the farmer, short term family needs, level of perception, social status, proximity and fragmentation of land and migration (labour). The introduction of such PLUP, which are mutually agreed by stakeholders and researchers improved the adoption of alternate plans and in turn increased the productivity of different crops by 14-48 per cent. Crop selection based on soil suitability, soil and water conservation measures using local resources coupled with application of required inputs were the key ingredients of this approach.

\section{Introduction}

India has an agrarian economy, which is strongly influenced by agriculture and allied enterprises. In India, nearly 50 per cent of lands suffer from severe land degradation. An increasing population has put more pressure on land, shortened fallow periods, increased deforestation and the use of animal dung for fuel and crop residues for fodder have drastically reduced in their contribution to soil enrichment. Soil erosion is rampant, as overgrazing and grazing on steep and unprotected slopes continue. In many areas, rainfall is becoming scarce and less reliable and under groundwater table has declined drastically. Due to these physical constraints and increased input costs the existing farming systems are no longer able to meet farmer's subsistence needs. This means that families have less reliable source of food.

Land use planning aims to encourage and assist land users in selecting options that increase their productivity, are sustainable and meet the needs of society (FAO, 1993). 
However, the two most crucial constraints to effective land use planning are conflicts on land use objectives between different stakeholders/interest groups (Hoanh and Roetter, 1998; de Haan and van Ittersum, 1999; Velayutham et al., 2002) and uncertinity about future land use objectives, land resources and exploitation technologies (Hoanh and Roetter, 1998).

In India, land use planning at local level are governed by farmers own requirement and market prices (Velayutham et al., 2001) rather than land suitability criteria (Ramamurthy et al., 2000) which is followed in developed countries. The land use plans suggested by national and state land use boards and research Institutes are seldom adopted by local communities/ stakeholders. The reason for non adaption are the initiatives usually come from government officials or others outside the local community and the techniques, resources and skills suggested rely heavily upon innovations developed at research stations. Moreover suggested plans developed from soil survey and land capability assessments (Patil et al., 2011; Dhanorkar et al., 2013), focuses upon the relationship between land use and its environmental compliance alone. The socioeconomic and political factors at the household, community and national levels, which influence land use, are often neglected. Also, there is a tendency to focus on land use per se and to neglect the details of land management and husbandry. Such land use plans have limited replicability because it involves considerable manpower and technical resources like maps and field staff and farmers do not easily comprehend the technicalities in this top down approach. As a result the implementation of land use planning is often difficult.

It has now been endorsed that successful land use planning depends on the participation of farmers. Thus, Participatory Land Use
Planning (PLUP) is considered as an important tool for sustainable resource management by local communities (Amler et al., 1999; Oltheten, 1999; Fagerstrom et al., 2003; Sawathvong, 2003). The aim of PLUP is to strike a balance between technical approach and farmer's requirements to maintain natural resources in sustainable manner. The plan should blend with biophysical, socio-economic, gender, policy, equity, community participation and institutioalised management of common property resources on a village or watershed basis. Keeping this in view, an attempt was made to introduce the participatory land use planning concept under Indian situation and assess its feasibility in Kokarda village of Nagpur district, Maharashtra.

\section{Materials and Methods}

\section{Location and Agro-climate of the study area}

Present study carried out under Technology Assessment and Refinement through InstituteVillage Linkage Programme. The village (Fig. 1 ), where participatory land use planning was implemented is situated at $21^{\circ} 20^{\prime} \mathrm{N}$ Latitude and $78^{\circ} 51^{\prime}$ E longitude on an altitude ranging from $340 \mathrm{~m}$ to $360 \mathrm{~m}$ above MSL. The geographical area of the village is 280 ha.

Agro climatically, the site is located in the Eastern Maharashtra plateau experiencing hot, dry, sub-humid eco-region (AESR-10.2) and are dominated by Vertisols (deep black soils) and associated soils. Moderately deep (100$150 \mathrm{~cm})$-to-deep $(>150 \mathrm{~cm})$ soils are found in valleys, while shallow $(<50 \mathrm{~cm})$ to medium deep (50-100 cm) soils occur on escarpments. The shallow soils are severely degraded, while deep soils have impaired drainage. The soil $\mathrm{pH}$ is alkaline, ranging from 8.1 to 8.6. Annual rainfall varies from over $975 \mathrm{~mm}$ to less than $800 \mathrm{~mm}$ per year and is received primarily 
during the southwest monsoon from second week of June to October. The maximum rainfall is received in the month of July. About 90 per cent rainfall received during June to September. Rainfall covers only 77 per cent of the gross annual water demand, even in normal rainfall year.

The dominant kharif (monsoon season) crops are sorghum, cotton and soybean. Chickpea is the main crop grown on residual soil moisture in the rabi (winter) season. Farmers have little access to timely, affordable credit and adoption of purchased agricultural inputs including fertilizer is limited.

\section{Soil Resource Inventory}

The soil resource inventory of Kokarda village (1:5000 scale) was carried out simultaneously as per the guidelines outlined by Soil Survey Manual (2000). The soil profiles were exposed and studied for morphological features and horizon-wise soil samples were collected and analysed for some important parameters as per the standard procedure. The soils were classified as per guidelines given in Key to Soil Taxonomy and identified 9 soil series in the village and are correlated with existing soils of Nagpur district. The soil series were evaluated for different crops suitability by using revised criteria developed by Naidu et al., (2006) and soil suitability map is prepared (Fig. 3).

\section{Methodology}

To identify the problems of land use and land use decisions, a participatory rural appraisal (PRA) was conducted in the summer 2000. The PRA was an interactive process spreading over 3 month period with planning occurring on site. Farmers identified the causes for land degradation and its effect on their livelihood (Fig. 2). Through focused PRA, farmers' perception and priorities of land use were identified. Land suitability map of village was discussed with each landholder and their opinion was incorporated before implementation. Most of the farmers were not inclined to accept the land suitability criteria, as there were numerous conflicts between suggested and preferred/practiced land use.

To understand the non-acceptance of suggested land suitability plan, resource mapping, transect walk and discussion with stakeholder was initiated to review the land use history, describe the village land condition and production, explain the reasons of land use change, define the socio-economic factors that affect their decision and propose the preferred future land use. To implement a negotiated scientifically optimal, yet socioeconomically tenable and acceptable by partners/stake holders, mutually agreed LUP options were evaluated for four years. Change in land use and productivity of different land uses during this period was also monitored.

\section{Results and Discussion}

\section{Soil site characteristics}

Based on soil survey data, soils of Kokarda village were classified in to nine series (Table 1) with maximum area (23.9\%) under shallow soils $(15 \mathrm{~cm})$, brown excessively drained loamy soils followed by very deep $(150 \mathrm{~cm})$, dark to very dark brown, moderately to well drained clayey soils $(14.6 \%)$. Soils are shallow at escarpment and deep in valley bottom. The surface texture of these soils varies from clay, clay loam, sandy clay loam and sandy loam and slope ranges from 1 to 30 percent in different landforms (Table 1). The soils are low in nitrogen and medium in phosphorus and potash. Nearly 258 ha is under different land use and remaining area in under settlement, drainage lines etc. Shallow soils, which are dominated in the village, are under kharif crops. 


\section{Soil suitability evaluation}

Soil suitability of village revealed that only 29.6 per cent area is suitable for all crops and nearly 25 per cent of the area is highly suitable for forest/ pasture and moderately suitable for kharif pulses (Fig. 3). Nearly 12.5 per cent is moderately suitable for sorghum, soybean and highly suitable for cotton varieties, 12.3 per cent of area is suitable only for forest and pasture and 10.9 per cent area is highly suitable for agroforestry and moderately suitable for pulses, cotton (varieties) and marigold.

The soil suitability ratings were compared to farmer's preference and perception at each land holding level. The perceptions did not match with the scientific soil suitability ratings. More than 60 per cent of the farmers' opinion on suitability of soil site characteristics (soil depth, slope per cent and stoniness) to different crops were corroborated with that of scientific criteria. But, in practice only 60 per cent of cotton, 50 per cent of sorghum, soybean and groundnut and 20 per cent of the orange area is being grown on suitable land (Fig. 4).

The other over riding factors that decides the practices of land use system in the village are: (1) economic condition of the farmer (2) short term family needs (3) level of perception or understanding (4) social status (5) fragmentation of land (6) risk management (7) proximity of land to the dwelling (8) migration (labour).

The analysis further revealed that even though farmers perceive the optimum LUP correctly, in practice, the existing land use is quite often objectively unsuitable under the current evaluation system in many ways. This is because of the fact that farmers have to strike a balance between available or mobilizable resources (physical and economic) and the diverse household needs and decide according to the market forces. Under such prevailing conditions, Participatory LUP interventions would play a pivotal role in optimizing the production of farmers' choice of crops and enterprises on sustainable basis.

\section{Identification of land use problems}

Initial Participatory Rural Appraisal (PRA) exercises revealed that due to increased population pressure, more area particularly those that was not suitable to the cultivation of crops were brought under cultivation. This led to decreased forest resources and climate change and finally degradation of land productivity and low crop productivity (Fig. 4).

\section{Land use dynamics}

Before implementation of PLUP, the initial land use and land cover was studied (Fig. 5). Out of 280 ha geographical area, 180 ha was under crop cultivation and nearly 32 ha area was under scrub forest. Out of 180 ha, 58 per cent of the area was under cotton hybrids, 21.6 per cent under cotton hybrids + sorghum, 9.3 per cent under sorghum and 5.3 per cent under citrus + cotton hybrids + soybean system. As per the soil suitability evaluation, only 35 per cent area is suitable for cotton hybrids, 40 per cent for sorghum and soybean. But actual practice was to grow cotton hybrids in almost all types soils because of socio-economic compulsions and other factors as discussed above. Due to this the productivity of cotton hybrids was very low ( 8 q seed cotton /ha) as compared to potential yield of village (10-14 q/ha).

These reasons were explained to stakeholder and different plans were drawn to different land holdings. Participatory land use options implemented in different soils integrating farmer's perception and scientific land evaluation is presented in Table 2 . 
Fig.1 Study area- location of Kokarda village

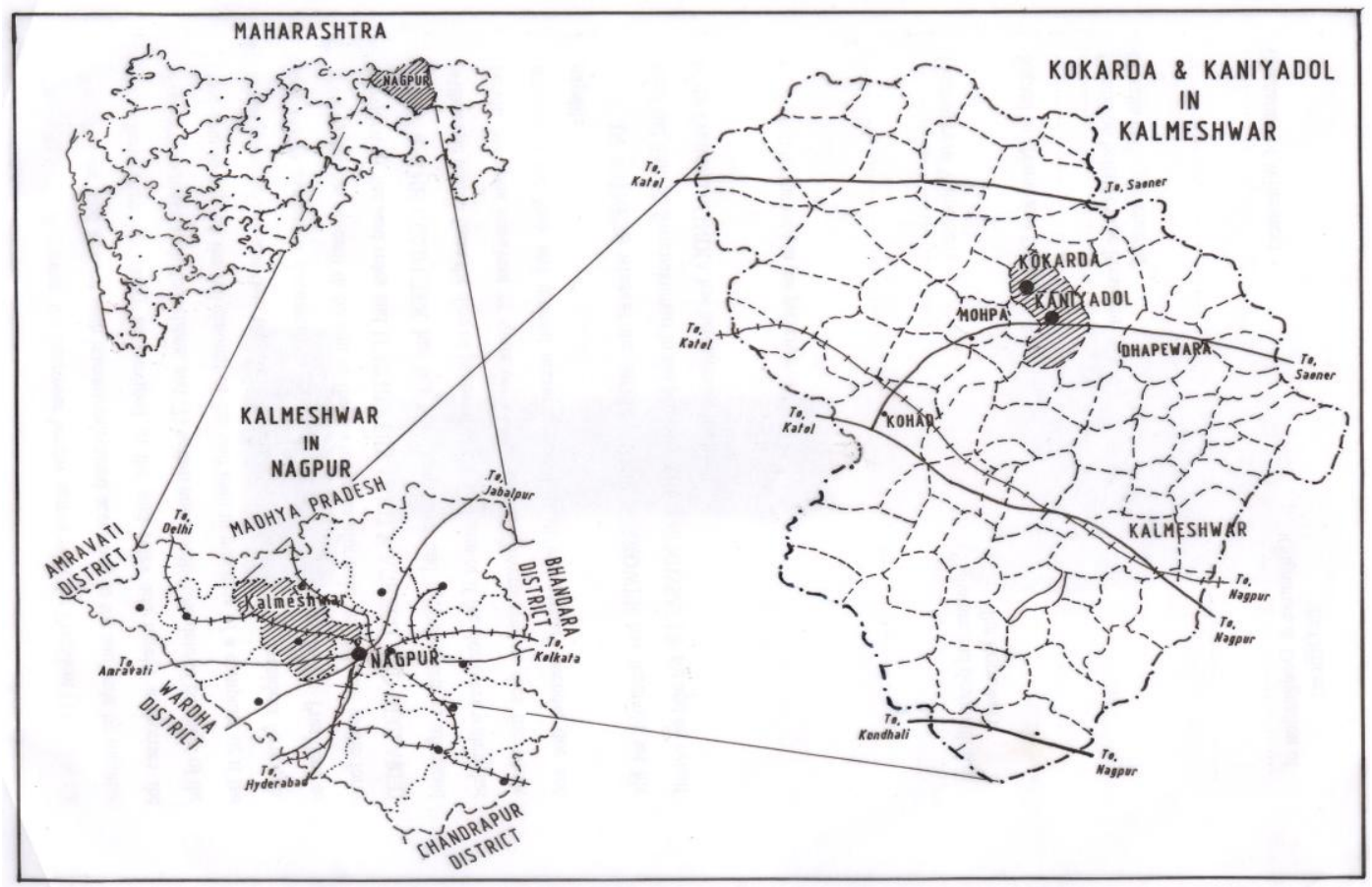

Fig.2 Problem analysis- Land use and land degradation

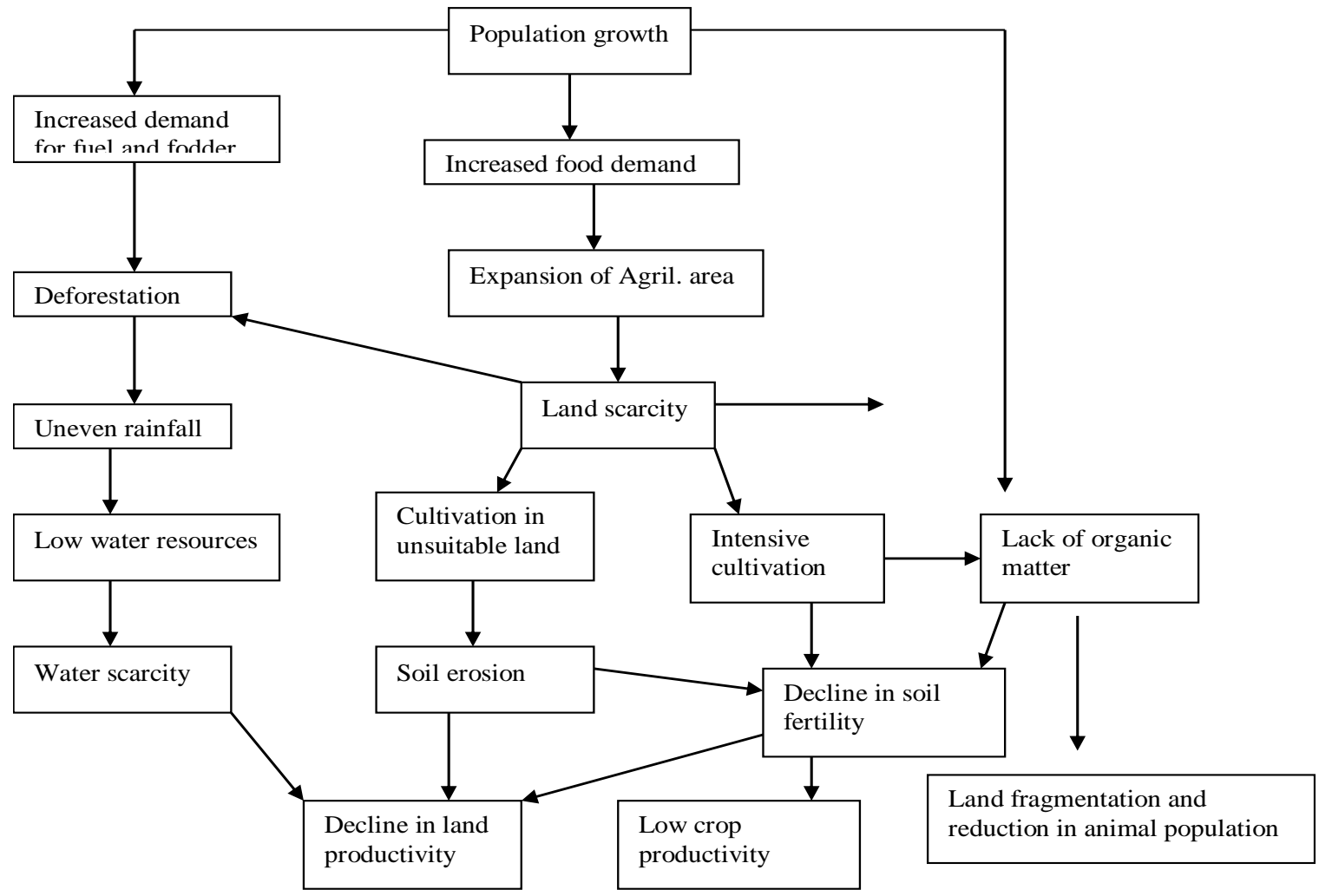


Fig.3 Soil suitability map of Kokarda

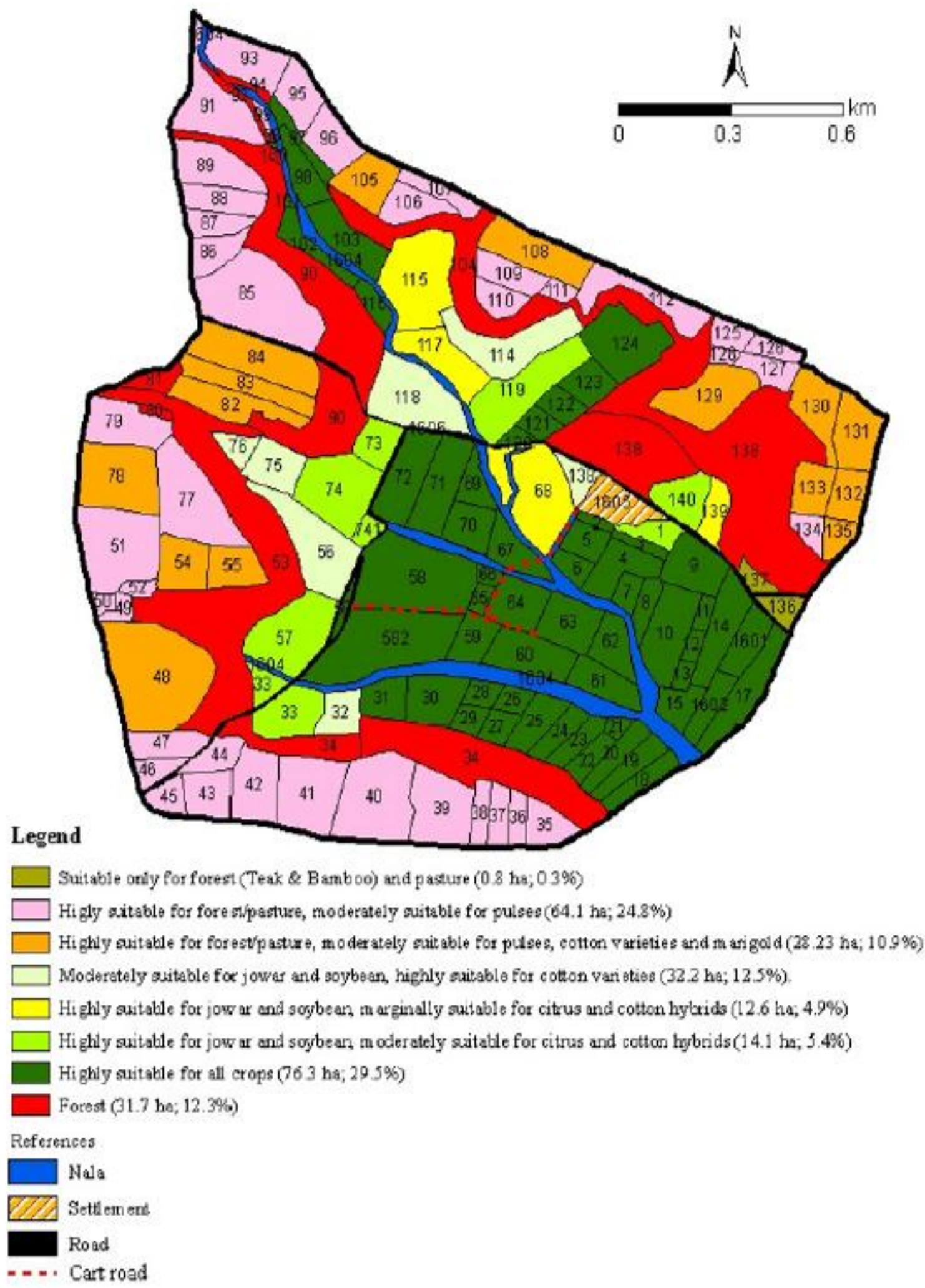


Fig.4 Perception and implementation of scientific soil-site suitability in the watershed

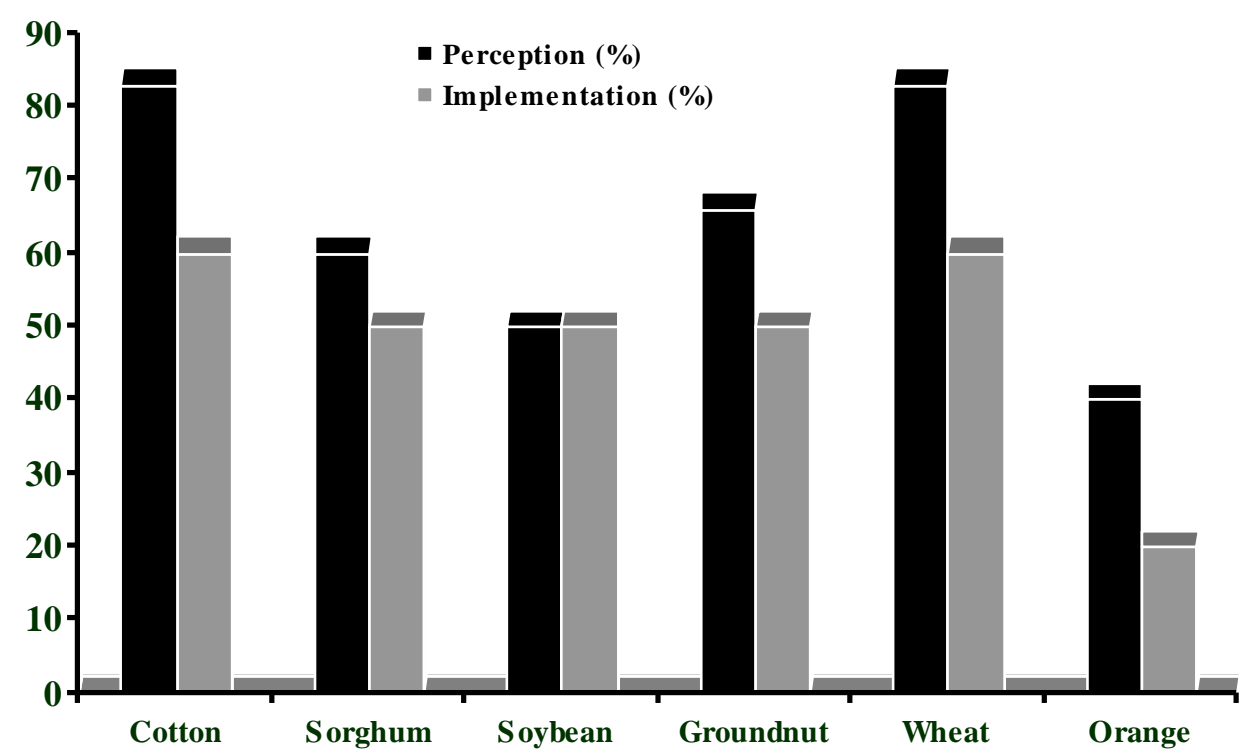

Fig.5 Land use land cover map of Kokarda village before implementation of PLUP

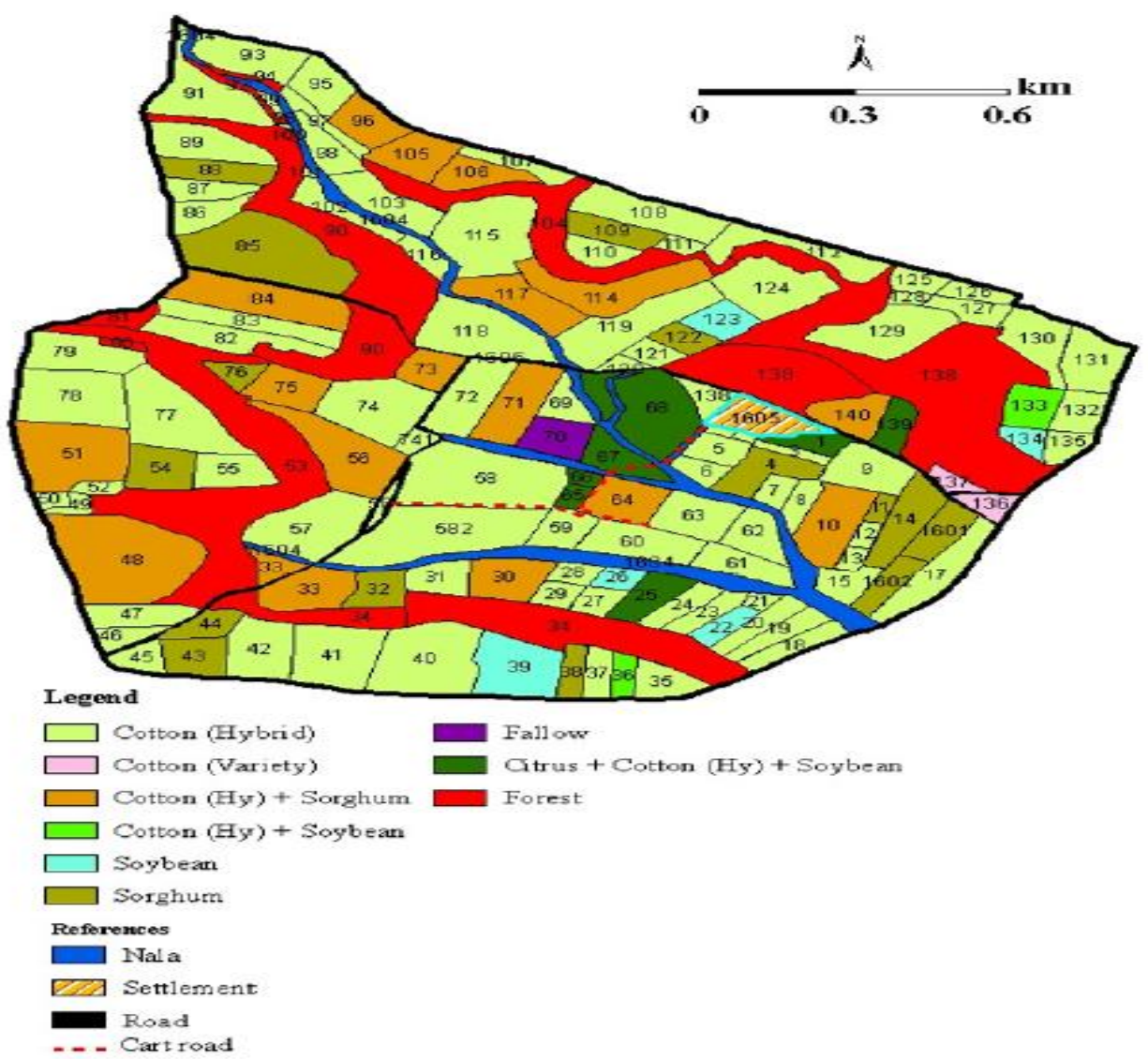


Fig.6 Land use land cover map of Kokarda village after implementation of PLUP

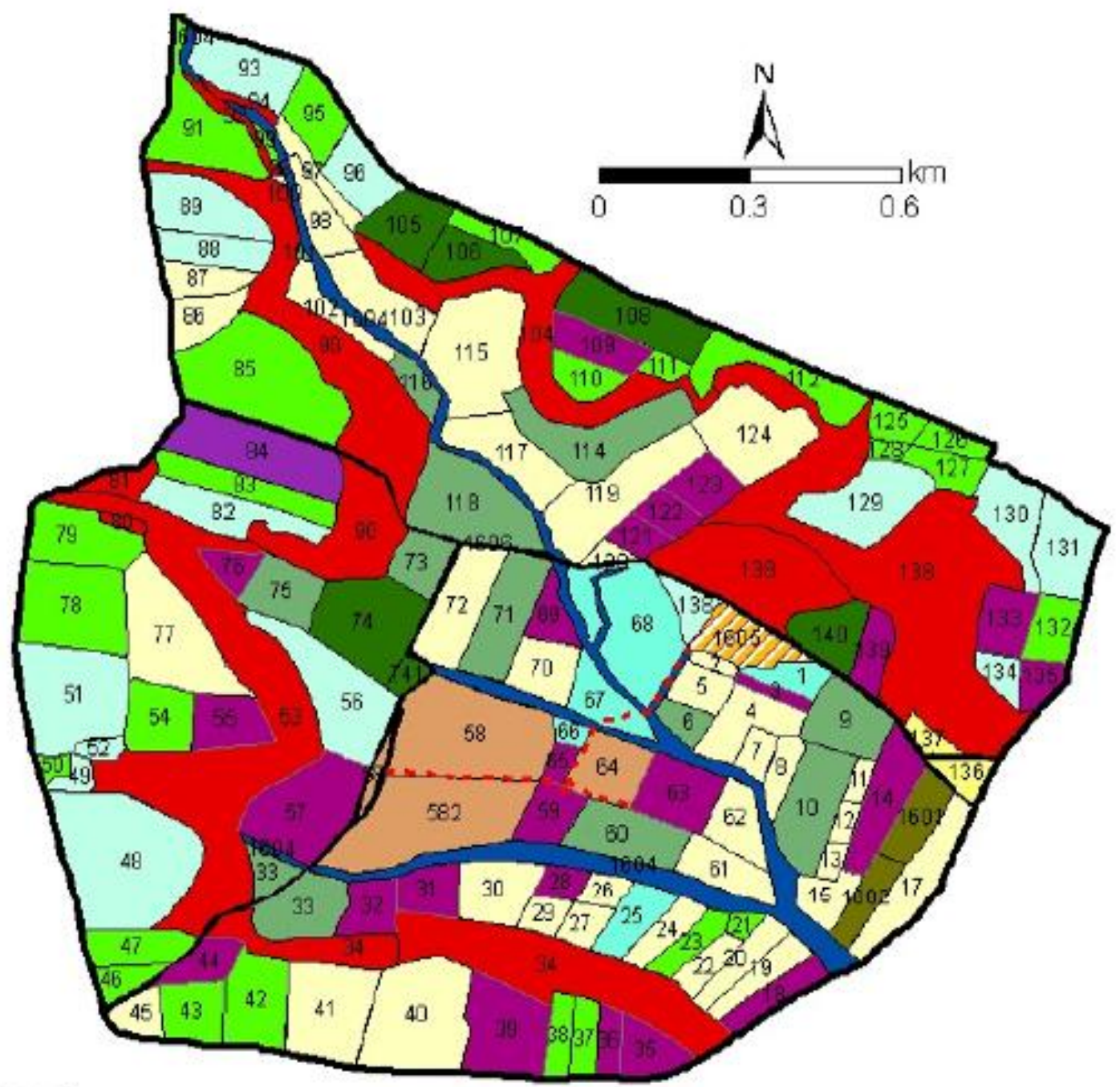

\section{Legend}

$\square$ Cotton (Hybrid)
Cotton (Varjety)
Cotton (Hy) + Sorghum $\square$ Cotton (Hy) + Soybean + Merrigold mul mulberry
Cotton (Hy) + Soybean 1 land
Cotton (Var) + Sorghum
Cotton (Nar) + Soybean

Soybean

Sorghum

References

Nala

Setilemen

Road

- - Cart road 
Table.1 Characteristics of soils of Kokarda village

\begin{tabular}{|c|c|c|c|c|c|c|c|c|c|c|c|c|}
\hline \multirow[t]{2}{*}{ Soil series } & \multirow[t]{2}{*}{ Characteristics } & \multirow{2}{*}{$\begin{array}{l}\text { Effective } \\
\text { soil depth } \\
(\mathrm{cm})\end{array}$} & \multirow[t]{2}{*}{$\begin{array}{l}\text { Major land use/ } \\
\text { constraints }\end{array}$} & \multicolumn{5}{|c|}{$\begin{array}{l}\text { Some soil physico-chemical properties (ranges) } \\
\text { through depths }\end{array}$} & \multirow[t]{2}{*}{ LCC* } & \multirow{2}{*}{$\begin{array}{l}\text { Irriga- } \\
\text { bility } \\
\text { sub } \\
\text { class }\end{array}$} & \multirow[t]{2}{*}{$\begin{array}{l}\text { Productivity } \\
\text { potential }\end{array}$} & \multirow{2}{*}{$\begin{array}{l}\text { Soil } \\
\text { taxonomy } \\
\text { (subgroup) }\end{array}$} \\
\hline & & & & $\begin{array}{l}\text { Clay } \\
(\%)\end{array}$ & $\begin{array}{l}\mathrm{OC} \\
(\%)\end{array}$ & $\begin{array}{l}\text { CEC cmol } \\
(+) / \mathrm{kg}\end{array}$ & $\begin{array}{l}\mathrm{CaCO} \\
{ }_{3}(\%)\end{array}$ & $\mathrm{pH}$ & & & & \\
\hline $\begin{array}{l}\text { Kokarda-1 } \\
\text { (Dongari } \\
\text { soil) }\end{array}$ & $\begin{array}{l}\text { Shallow, brown, loamy, } \\
\text { excessively drained soils on } \\
\text { hills and plateau (1-15\%) }\end{array}$ & 15 & $\begin{array}{l}\text { - Sorghum, cotton, } \\
\text { pigeonpea } \\
\text { - very low WHC, low } \\
\text { response to crops and } \\
\text { management practices }\end{array}$ & 33.5 & 0.50 & 25.5 & - & 6.8 & IVes & 4 st & Very low & $\begin{array}{l}\text { Lithic } \\
\text { Ustorthents }\end{array}$ \\
\hline $\begin{array}{l}\text { Kokarda-2 } \\
\text { (Bardi soil) }\end{array}$ & $\begin{array}{l}\text { Moderately deep, dark brown, } \\
\text { clayey, well-drained soils on } \\
\text { plateau (1-8\%) }\end{array}$ & 50 & $\begin{array}{l}\text {-Cotton, pigeonpea, } \\
\text { sorghum } \\
\text { - Low to medium WHC }\end{array}$ & $\begin{array}{l}52.6- \\
59.5\end{array}$ & $\begin{array}{l}0.76- \\
1.07\end{array}$ & $34.8-38$ & - & $\begin{array}{l}6.5- \\
6.6\end{array}$ & IIIes & $2 \mathrm{st}$ & Medium & $\begin{array}{l}\text { Typic } \\
\text { Haplustepts }\end{array}$ \\
\hline $\begin{array}{l}\text { Kokarda-3 } \\
\text { (Pathari soil) }\end{array}$ & $\begin{array}{l}\text { Shallow, dark brown, clayey, } \\
\text { excessively drained soils on } \\
\text { escarpment (15-50\%) }\end{array}$ & 22 & $\begin{array}{l}\text {-Natural vegetation } \\
\text {-Very shallow soils } \\
\text { with low WHC }\end{array}$ & $\begin{array}{l}38.5- \\
45.5\end{array}$ & $\begin{array}{l}0.85- \\
1.56\end{array}$ & $34.5-39.2$ & - & $\begin{array}{l}6.6- \\
6.8\end{array}$ & IVes & 6 st & Very low & $\begin{array}{l}\text { Typic } \\
\text { Ustorthents }\end{array}$ \\
\hline $\begin{array}{l}\text { Kokarda-4 } \\
\text { (Dongari } \\
\text { soil) }\end{array}$ & $\begin{array}{l}\text { Moderately deep, dark brown, } \\
\text { clayey skeletal, well-drained } \\
\text { soils on escarpment (15-30\%) }\end{array}$ & 44 & $\begin{array}{l}\text {-Forest land } \\
\text { - Low to medium WHC }\end{array}$ & $\begin{array}{l}54.5- \\
60.5\end{array}$ & $\begin{array}{l}1.28- \\
1.72\end{array}$ & $40.5-44.2$ & - & $\begin{array}{l}6.7- \\
6.9\end{array}$ & IVes & $6 s t$ & Very low & $\begin{array}{l}\text { Lithic } \\
\text { Ustorthents }\end{array}$ \\
\hline $\begin{array}{l}\text { Kokarda-5 } \\
\text { (Dongari } \\
\text { soil) }\end{array}$ & $\begin{array}{l}\text { Shallow, brown to dark brown, } \\
\text { clayey, well drained soils on } \\
\text { pediment }(3-30 \%)\end{array}$ & 11 & $\begin{array}{l}\text {-Sorghum, Pigeonpea, } \\
\text { gram, wheat, vegetables } \\
\text { - Very low WHC }\end{array}$ & 37.5 & 0.53 & 34.5 & 12.2 & 8.0 & IIIes & $3 \mathrm{~s}$ & Low & $\begin{array}{l}\text { Lithic } \\
\text { Ustorthents } \\
\text { (cal.) }\end{array}$ \\
\hline $\begin{array}{l}\text { Kokarda-6 } \\
\text { (Bardi soil) }\end{array}$ & $\begin{array}{l}\text { Moderately deep, brown, } \\
\text { clayey, well drained soils, on } \\
\text { pediment }(1-8 \%)\end{array}$ & 36 & $\begin{array}{l}\text {-Sorghum, cotton, } \\
\text { pigeonpea } \\
\text {-Low WHC }\end{array}$ & $\begin{array}{l}36.5- \\
47.5\end{array}$ & $\begin{array}{l}0.58- \\
0.69\end{array}$ & $33.3-44.2$ & $\begin{array}{l}4.2- \\
4.6\end{array}$ & $\begin{array}{l}7.8- \\
7.9\end{array}$ & IIIes & $3 \mathrm{~s}$ & Low & $\begin{array}{l}\text { Typic } \\
\text { Haplustepts } \\
\text { (cal.) }\end{array}$ \\
\hline $\begin{array}{l}\text { Kokarda-7 } \\
\text { (Bardi soil) }\end{array}$ & $\begin{array}{l}\text { Deep, brown to dark brown, } \\
\text { clayey, well to moderately } \\
\text { drained soils on pediment (1- } \\
8 \% \text { ) }\end{array}$ & 60 & $\begin{array}{l}\text {-Sorghum, cotton, } \\
\text { wheat, vegetables, } \\
\text { orange } \\
\text { - Low to medium WHC }\end{array}$ & $\begin{array}{l}42.5- \\
50.5\end{array}$ & $\begin{array}{l}0.56- \\
0.75\end{array}$ & $41.2-48.7$ & $\begin{array}{l}10.7- \\
14.1\end{array}$ & $\begin{array}{l}8.1- \\
8.4\end{array}$ & IIIes & 3es & Low & $\begin{array}{l}\text { Typic } \\
\text { Haplustepts } \\
\text { (cal.) }\end{array}$ \\
\hline $\begin{array}{l}\text { Kokarda-8 } \\
\text { (Halki } \\
\text { kanhar) }\end{array}$ & $\begin{array}{l}\text { Very deep, very dark brown, } \\
\text { clayey, moderately to well } \\
\text { drained soils on piedmont (1- } \\
8 \%)\end{array}$ & 97 & $\begin{array}{l}\text {-Cotton, sorghum, } \\
\text { pigeonpea, wheat, } \\
\text { gram, vegetables, } \\
\text { orange } \\
\text {-Medium to high WHC }\end{array}$ & $53.5-59$ & $\begin{array}{l}0.69- \\
0.82\end{array}$ & $50.6-55.4$ & $\begin{array}{l}8.4- \\
17.3\end{array}$ & $\begin{array}{l}8.1- \\
8.5\end{array}$ & II s & $2 \mathrm{~s}$ & Medium & $\begin{array}{l}\text { Vertic } \\
\text { Haplustepts } \\
\text { (cal.) }\end{array}$ \\
\hline $\begin{array}{l}\text { Kokarda-9 } \\
\text { (Bhari } \\
\text { kanhar) }\end{array}$ & $\begin{array}{l}\text { Very deep, dark brown to very } \\
\text { dark brown, clayey, moderately } \\
\text { to well drained soils, on } \\
\text { piedmont }(1-3 \%)\end{array}$ & 150 & $\begin{array}{l}\text {-Cotton, sorghum, } \\
\text { pigeonpea, wheat, } \\
\text { gram, vegetables, } \\
\text { orange, sugar cane } \\
\text {-Medium to high WHC }\end{array}$ & $\begin{array}{l}53.0- \\
71.5\end{array}$ & $\begin{array}{l}0.24- \\
0.89\end{array}$ & $45.6-56.9$ & $\begin{array}{l}13.5- \\
18.0\end{array}$ & $\begin{array}{l}8.2- \\
8.8\end{array}$ & II d & $2 d$ & Medium & $\begin{array}{l}\text { Typic } \\
\text { Haplusterts } \\
\text { (cal.) }\end{array}$ \\
\hline
\end{tabular}

*LCC- Land capability class.

Names in parenthesis are local name 
Table.2 Mutually agreed land use options for different soils based on farmer's perception and scientific land evaluation

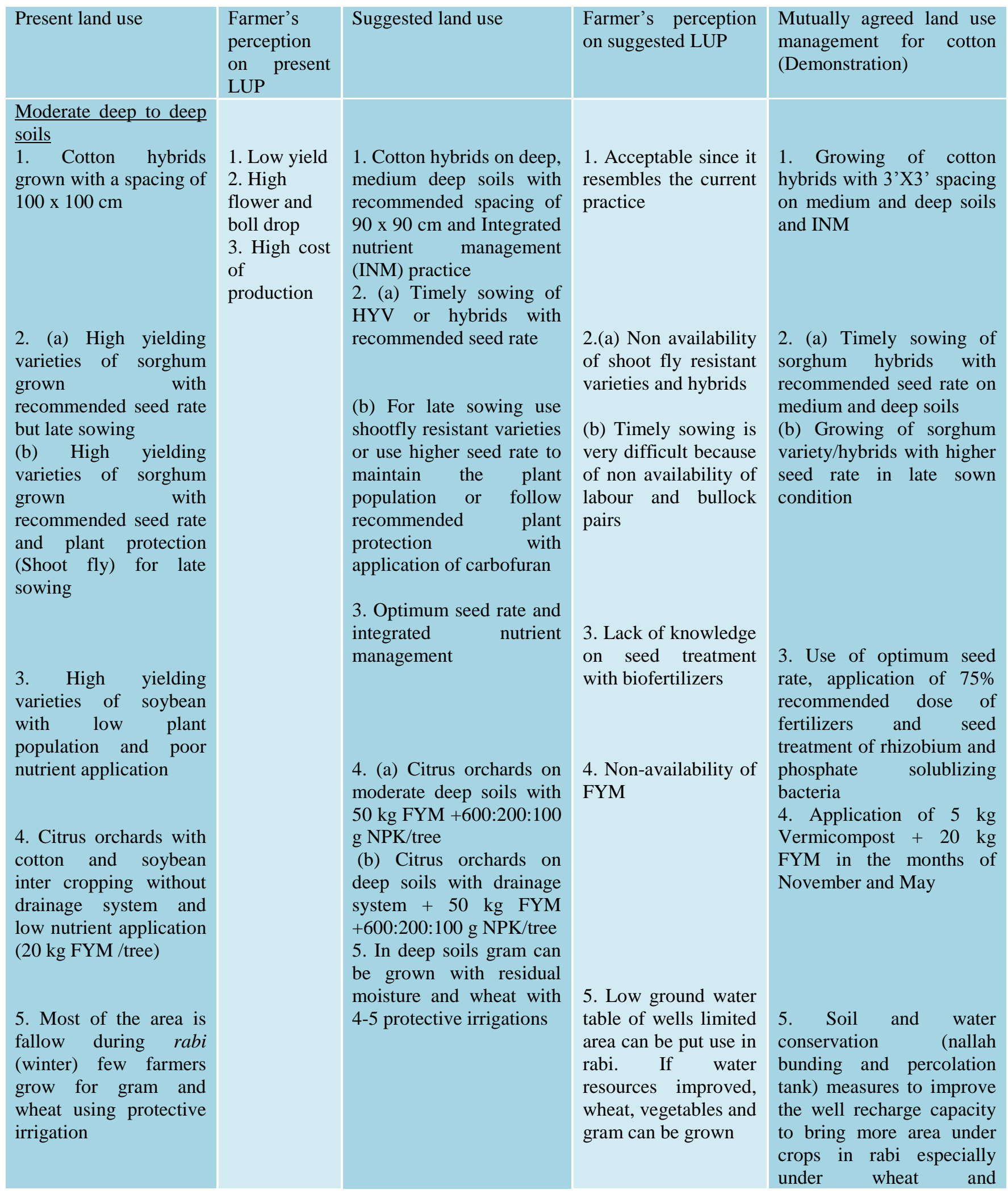




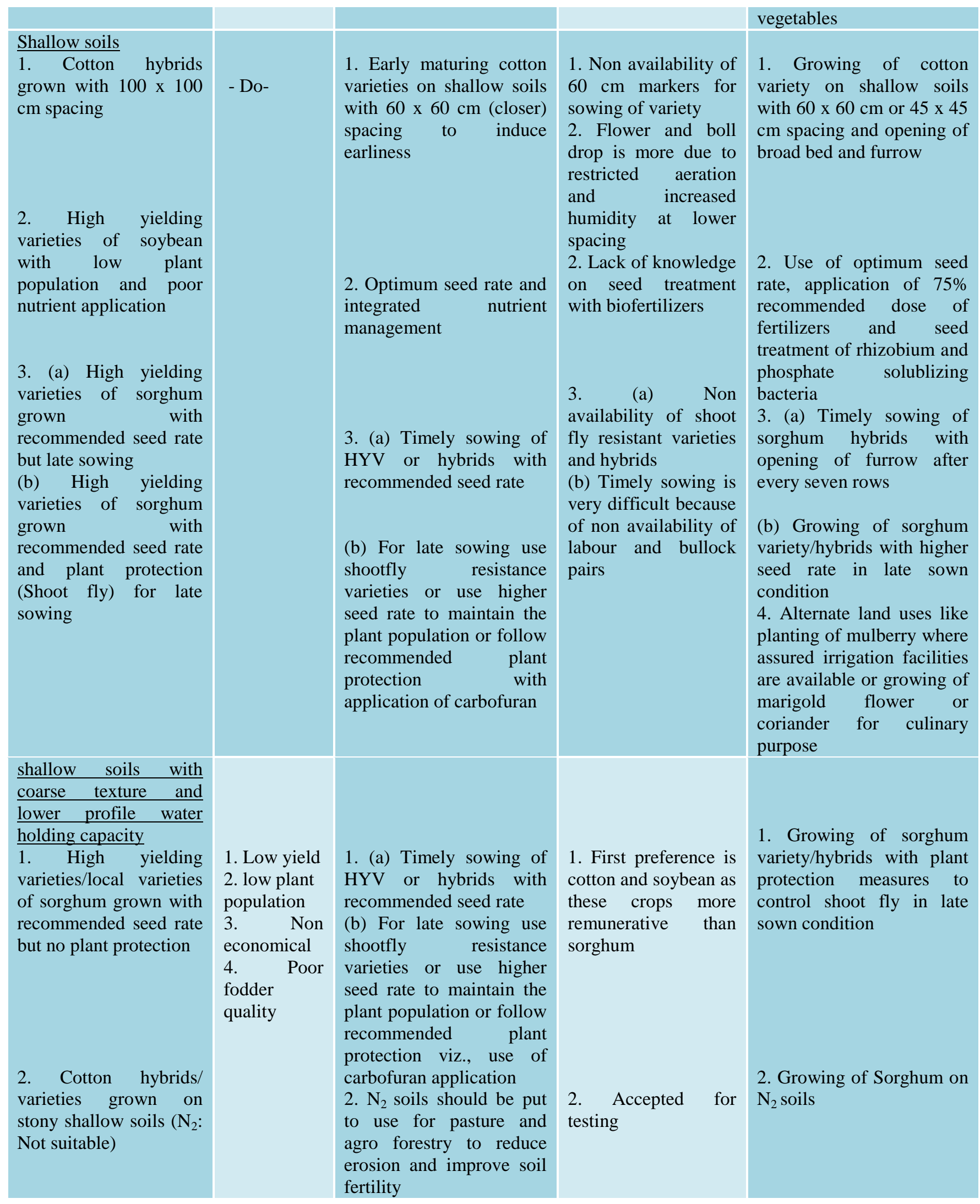


Table.3 Average yield of crops for pre and post PLUP period in Kokarda Villages

\begin{tabular}{|l|c|c|c|}
\hline \multirow{2}{*}{ CROPS } & \multicolumn{2}{|c|}{ Average yield (Kg/ha) } & Per cent increase \\
\hline Rainfed & Pre project & Post project & \\
\hline Sorghum & 1540 & 2170 & 40.9 \\
\hline Cotton Variety & 500 & 700 & 40.0 \\
\hline Hybrid & 810 & 1080 & 33.3 \\
\hline Soybean & 1020 & 1340 & 31.4 \\
\hline Pigeon pea & 600 & 750 & 25.0 \\
\hline Ground nut & 925 & 1150 & 24.3 \\
\hline Local fodder sorghum & 2500 & 10,000 & 400 \\
\hline Irrigated & & & \\
\hline Wheat & 1500 & 1730 & 15.3 \\
\hline Gram & 650 & 965 & 48.5 \\
\hline Brinjal & 14000 & 16000 & 14.3 \\
\hline Orange & 21,500 & 26,500 & 23.2 \\
\hline
\end{tabular}

The analysis of changes in land use after four years of implementation indicated that the area under crop cultivation increased from 180 ha to 197 ha (Fig. 6) by bringing current fallow and other pasture land under agroforestry cultivation. The area under cotton hybrid, cotton hybrid + sorghum and citrus has been declined from 104 to 55 ha, 38.8 to 11.9 ha and 9.6 to 6.8 ha, respectively.

Whereas, area under cotton varieties (which can be grown on shallow soils, not suitable for hybrid cotton), cotton hybrids + soybean, cotton varieties + sorghum, cotton varieties + soybean, soybean and sorghum increased from 0.8 to 23.9 ha, 1.72 to 12.9 ha, 0 to 8.2 ha, 0 to 8.8 ha, 6.1 to 29.3 ha and 16.6 to 37.7 ha, respectively. The area under soybean and sorghum fluctuated alternatively depending on market prices.

\section{Evaluation of PLUP}

Each land use plan was evaluated for its productivity, economic viability and farmer's acceptance after the crop cycle and modifications were made while implementing the plan if stakeholder found it difficult to implement the agreed land use plans.

The increase in productivity of different crops following the implementation of PLUP ranges from 14 to 48 per cent (Table 3 ). The yield levels of dryland as well as irrigated crops increased. This indicates that the PLUP created awareness and build the knowledge base among the stakeholders to use available natural resources more appropriately for improving the productivity.

Impact analysis of different land use management practices over different crops indicated that timely sowing of sorghum is being practiced by 90 per cent of the stakeholders and consequently the shoot fly incidence in sorghum reduced from 59 to 29 percent. Similarly, in cotton the adoption of Azotobacter seed treatment increased from 5 to 36 per cent and farmers practicing reduced spacing for cotton variety $(45 \times 45 \mathrm{~cm})$ increased to 12 per cent. In soybean, the number of farmers adopting optimum seed rate has rised to 75 per cent, rhizobium and Phosphate solubilizing Bacteria (PSB) use has 
been increased to 90 and 30 per cent, respectively. This increased adoption of technologies shows the direct impact on improvement of stakeholder's livelihood and acceptance. Adoption of scientifically feasible, economically viable and stakeholder agreed technologies with soil suitable land uses contributed for increased productivity of crops.

Land use in the study area is very dynamic. Economic situation of the farmer, short-term family needs, level of perception or understanding about land resources and risk management strategies, social status, fragmentation of land, proximity of land, migration (labour) and market forces decides the land use. The introduction of village based participatory land use planning has made it possible for the villagers to practice proper land use management on their farms. Land use changed even more favourably than farmer's preference by demonstrating mutually agreed land use plans. Productivity level of rainfed crops increased in the range of 24-40 per cent whereas, in irrigated situation between 14- 48 percent. Improved production at farm level is now realized as a result of practicing soil suitable crop selection, soil and water conservation measures coupled with application of required inputs (organic and inorganic fertilizers). PLUP enhanced the livelihood of people by improving cash flow and conserving the natural resources of the village. Although this exercise was operational for five years, the degree of change of attitude by the villagers towards adopting participatory land use planning is considered satisfactory.

\section{Acknowledgement}

Authors thank all the participating farmers for sharing their valuable experience and providing information for this paper. The financial help rendered through the World
Bank funded National Agricultural Technology project (NATP) for conducting this study is gratefully acknowledged.

\section{References}

Ameler, B. D., Betke, H. Eger, C. Ehrich, U. Hoesle, A. Kohler, C. Kosel, A. V. Lossau, W. Lutz, U. Muller, T. Schwedersky, S. Seidemann, M. Siebert, A. Trux and W. Zimmermann. 1999. Land use planning Methods, Strategies and Tools. GTZ.

De Haan, J. and M.van Ittersum, 1999. Introductory module Quantative Analysis of Agro-ecosystems (QUASIintro): onderwijselement F350323.Wageningen University and Research center.

Dhanorkar, B.A., Arti koyal, D.S. Mohekar, L.G.K. Naidu, R.S. Reddy and Dipak sarkar. 2013. Soil resource assessment for crop planning in Medak district, Andhra Pradesh. Agropedology 23(1), 23-29

Fagerstrom, M.H.H., I. Messing and Z.M. Wen. 2003. A participatory approach for integrated conservation planning in a small catchment in Loess Plateau, China-Part I. Aproach and methods. Ctena. 54: 255-269.

FAO. 1993. Guidelines for land use planning. p. 36. FAO development series1 FAO, Rome.

Hoanh, C.T. and R. Roetter. 1998. Towards decision support systems for land use planning. In: Eds. R. Roetter, C. T. Hoanh and P. S. Teng. A system approach to analyzing land use options for sustainable rural development in south and southeast Asia. Pp. 6-13. IRRI Discussion Paper series.

Naidu, L.G. K., Ramamurthy, V., Chall, O., Hegde, R. and P. Krishanan. 2006. Manual soil-site suitability criteria for 
major crops. NBSS Publ. No.129, NBSS \&LUP, Nagpur, 118 pp.

Oltherten, T.M.P. 1999. Participatory approaches to planning for community forestry. Results and lesson from case study in Asia, Africa and ltin America. Forest, tree and people programmeForestry department.

Patil, P.L., L. Vinay and G.S. Dasog. 2011. Land evaluation of Bhanapur microwatershed in Northern Dry Zone of Karnataka. Agropedology 21(2), 10-16. Ramamurthy, V., N.G. Patil, Bankar, W.V., K.S. Gajbhiye and M.V. Venugopalan, 2000. Land use planning: Farmers' perception and priorities-A case study. Paper submitted for National Syposium on Perspectives and policies for land use planning, held at NBSS\&LUP from $27^{\text {th }}$ Dec., 2000

Soil Survey Division Staff. 2000. Soil Survey Manual, USDA Hand Book No.18 (Indian print)

Swathvong, S., 2003. Participatory land use management planning in biodiversity conservation areas of Lao PDR. ActaUniversity-Agriculturae- SueciaeSilvestria, 2003, No. 267, 44pp, +Papers I-V.

Velayutham, M., Ramamurthy, V. and M. V. Venugopalan, 2001. Agricultural Land Use Planning- from theoretical perspectives to participatory action plan in the Indian context. The Land. 6(4): $45-60$

\section{How to cite this article:}

Ramamurthy, V. 2018. Participatory Land Use Planning to Enhance Rural Livelihoods in Eastern Maharashtra Plateau of Central India. Int.J.Curr.Microbiol.App.Sci. 7(04): 867-880. doi: https://doi.org/10.20546/ijcmas.2018.704.094 